\title{
Race, homelessness and inner-city policy in 1980s Britain
}

\author{
Phil Child ${ }^{\star \dagger}$ \\ Department of Social Policy, Sociology and Criminology, School of Social Policy, Muirhead Tower, \\ University of Birmingham, Birmingham, B15 2TT, UK \\ ${ }^{*}$ Corresponding author. Email: p.child@bham.ac.uk
}

\begin{abstract}
This article utilizes an organizational history of the Birmingham-based Handsworth Single Homeless Action Group (HSHAG) to explore black youth homelessness and inner-city policy in 1980s Britain. It draws upon under-used charity archives to intervene in recent debates, considering the part played by the voluntary sector within the Thatcher administrations' inner-city policies and what targeted funding of this kind reveals about the remaking of the welfare state in these years. First, it introduces HSHAG, setting out the context of inner-city funding programmes, before questioning how sustainable this might have been for voluntary organizations engaged in supporting the homeless population. Secondly, it examines the effects of housing privatization and unemployment on HSHAG's attempts to advise homeless black individuals and assert their rights as citizens to state support. Together, it exposes the role of the voluntary sector in welfare state restructuring and considers how this change made the task of homelessness organizations Herculean.
\end{abstract}

\section{Introduction}

At the conclusion of the 1983 Central Television documentary Homeless in Handsworth, housing worker Dave Butchere described the despair of homeless clients who could not be helped, recounting that they would 'sit there, sometimes for hours, and simply cry. ${ }^{1}$ Butchere worked for the Handsworth Single Homeless Action Group (HSHAG), an advocacy organization operating in the black innercity area of Handsworth in Birmingham, primarily within the African-Caribbean community. Throughout the late 1970s and 1980s, the group supported young

\footnotetext{
${ }^{\dagger}$ The author wishes to thank Isabel Galleymore, John Mohan, Aaron Andrews, Alistair Kefford and Dan Warner for their helpful comments on earlier drafts of this article. The research on which this article is based was part of a major project directed by John Mohan at the Third Sector Research Centre, funded by a Leverhulme Trust Research Project Grant (RPG-2017-102, Community-level perspectives on postwar change in the British voluntary sector).

${ }^{1}$ Media Archive for Central England (MACE), Homeless in Handsworth (1983). I was sadly unable to contact Dave Butchere in the course of my research.

(C) The Author(s), 2021. Published by Cambridge University Press. This is an Open Access article, distributed under the terms of the Creative Commons Attribution licence (http://creativecommons.org/licenses/by/4.0/), which permits unrestricted re-use, distribution and reproduction, provided the original article is properly cited.
} 
single homeless black men and women between the ages of 16 and 21, with the vast majority also unemployed. HSHAG argued that the meteoric rise in youth homelessness and unemployment was hardly coincidental, nor could it be 'considered in isolation from the effects of the [Thatcher] government's disastrous economic and social policies'. ${ }^{2}$ The number of homeless households accepted by English local authorities more than doubled between 1980 and 1991: from 60,400 households to 144,780 households. ${ }^{3}$ This figure excluded the large numbers not supported, many of whom were young and single: 585,830 not accepted against 503,560 accepted across Britain between 1981 and 1986. ${ }^{4}$ Their exclusion was due to the provisions of the 1977 Housing (Homeless Persons) Act, which deemed those in priority need as: those with dependent children; pregnant women; those made homeless due to a disaster such as a fire or flood; and those otherwise vulnerable due to old age, physical or mental health problems. ${ }^{5}$ Outside this definition of priority need were the young and single who may have been vulnerable for other reasons, and, indeed, in the case of HSHAG clients, almost always were. Paradoxically, the augmentation of urban policy with targeted funds for inner-city areas such as Handsworth during the period enabled HSHAG to expand their operations even as the homelessness and unemployment figures spiralled. This article will consider how an otherwise obtuse set of inner-city policies were pertinent to black youth homelessness in 1980s Handsworth. Through a case-study of Britain's second city, the late twentieth-century urban crisis can be humanized as well as visualized by situating its effects on people of colour within a broader process of Thatcherite neoliberal welfare restructuring. ${ }^{6}$

Scholarly interest in inner-city areas such as Handsworth and in inner-city policy has experienced a recent revival. From the late 1960s to the early 1990s, social policy scholars, political scientists and geographers appraised inner-city policies from a variety of angles. Perhaps the most constant was that such policies involved a spatial reorientation of welfare spending towards 'concentrations of deprived people' and hence appeared to step away from a universal welfare state. ${ }^{7}$ Even after 1977, when 'economic improvement' and stimulating 'enterprise culture' became core aims of inner-city policy as a means of creating jobs, poverty reduction

\footnotetext{
${ }^{2}$ Institute of Race Relations (IRR), Handsworth Collection files (H), 01/04/04/01/14/07, HSHAG, Report 4 (1982), 1.

${ }^{3}$ I. Anderson, 'Housing, homelessness and the welfare state in the UK', European Journal of Housing Policy, 4 (2004), 369-9, at 376. For this statistic, Anderson draws on a 2002 study of English local authorities rather than the UK as a whole.

${ }^{4}$ M. Drake, 'Fifteen years of homelessness in the UK', Housing Studies, 4 (1989), 119-32, at 121. Figures calculated from Table 1, 'Homeless households: applications and acceptances: 1971-1986', which Drake created from Department of the Environment homelessness statistics.

${ }^{5} 1977$ Housing (Homeless Persons) Act, s.2: www.legislation.gov.uk/ukpga/1977/48/section/2/enacted, accessed online 9 Aug. 2021. The Act was consolidated in the 1985 Housing Act. Vulnerable young people would not be included in this definition of priority need until the introduction of the 2002 Homelessness (Priority Need for Accommodation) (England) Order, but Isobel Anderson and Nicholas Crowson, both of whom I draw upon for this article, have mistakenly referred to the 2002 definition of priority need when describing the 1977/85 definitions.

' I take 'neoliberalism' to be the normalization of market sensibilities within all corners of society, which led an increasingly punitive welfare regime directed at 'unproductive' recipients.

${ }^{7}$ N. Deakin and J. Edwards, The Enterprise Culture and the Inner City (London, 1993), 16-17.
} 
remained a policy objective. ${ }^{8} \mathrm{Jim}$ Tomlinson has more recently drawn attention to the economic context of late twentieth-century Britain, arguing that the effect of de-industrialization was to 'increase insecurity and hence harm economic welfare'. ${ }^{9}$ Urban historians have especially been prompted to consider how the collapse of industrial manual employment might have played out in British cities. ${ }^{10}$ Commenting on this theme, Otto Saumarez Smith writes that within the inner cities 'many of the larger processes negatively affecting British society could be seen most vividly, whether it was unemployment, de-industrialization, social polarization or antagonistic race relations'. ${ }^{11}$ This article contributes to this growing literature, considering what a voluntary organization working with a precarious section of the urban black community reveals about welfare state restructuring in the context of de-industrialization. An extraordinary aspect of inner-city policy was the 'appropriation, by subterfuge' of the voluntary sector into state orbit, as the relationship between state funder and voluntary recipient tightened. ${ }^{12}$ The fact that 81 per cent of HSHAG's income was derived from inner-city funding in 1984 is certainly suggestive. ${ }^{13}$ With rising unemployment and benefit payments which failed to keep pace with inflation, the problems raised by bountiful inner-city funding and paltry local authority budgets were all too apparent.

Visualizing Handsworth in a recent history, Kieran Connell comments that 'sociological investigations, sensationalist newspaper stories, and television news bulletins' were indicative of intense public interest in a riotous site of supposed racial discord. ${ }^{14}$ The young people supported by HSHAG were essential to this portrayal. Rob Waters writes that 'black youth' were depicted by a range of forces as a 'social problem caused by inadequate family lives, conflicted or wanting social identities, and poor integration'. 15 This othering of young black Britons in late postcolonial Britain requires us, as Kennetta Hammond Perry has argued, to look to the state to better understand 'how the politics of race bears upon [the] everyday lives [of black British people] as citizens with rights' ${ }^{16}$ As an advocacy body, rather than a self-help organization composed of the homeless themselves, HSHAG were part of an ecosystem of voluntary organizations addressing an indifferent if not

\footnotetext{
${ }^{8}$ Ibid., $20-1$.

${ }^{9} \mathrm{~J}$. Tomlinson, 'De-industrialization not decline: a new meta-narrative for post-war British history', Twentieth Century British History, 27 (2016), 76-99, at 97.

${ }^{10}$ For examples of this research, see A. Andrews, 'Dereliction, decay and the problem of de-industrialization in Britain, c. 1968-1977', Urban History, 47 (2020), 236-56; A. Kefford, 'Disruption, destruction and the creation of "the inner cities": the impact of urban renewal on industry, 1945-1980', Urban History, 44 (2017), 492-515; S. Kenny, 'A "radical project": youth culture, leisure, and politics in 1980s Sheffield', Twentieth Century British History, 30 (2019), 557-84; O. Saumarez Smith, 'Action for cities: the Thatcher government and inner-city policy', Urban History, 47 (2020), 274-91.

${ }^{11}$ Saumarez Smith, 'Action for cities', 291.

${ }^{12} \mathrm{~S}$. Macgregor and B. Pimlott, 'Action and inaction in the cities', in S. Macgregor and B. Pimlott (eds.), Tackling the Inner Cities: The 1980s Reviewed, Prospects for the 1990s (Oxford, 1990), 1-22.

${ }^{13}$ Birmingham Archives (BA), Barrow Cadbury Collection files (BCC), MS/1579/2/7/3/29, HSHAG, Report 6 (1984), 16.

${ }^{14} \mathrm{~K}$. Connell, Black Handsworth: Race in 1980s Britain (Oakland, 2019), 13.

${ }^{15}$ R. Waters, Thinking Black: Britain, 1964-1985 (Oakland, 2019), 179.

${ }^{16} \mathrm{~K}$. Hammond Perry, London Is the Place for Me: Black Britons, Citizenship and the Politics of Race (Oxford, 2015), 247.
} 
actively hostile state as an intermediary on behalf of deprived sections of the black community, aiming to mitigate racialized inequality through asserting the rights of their clients to claim social welfare. Where the state would not respond, many of the young homeless participated in outbreaks of violence as a form of 'collective bargaining by riot'. ${ }^{17}$ Surveying the work of HSHAG is thus a means of understanding what the 'urban crisis' meant for those living it.

Central to this story is the privatization of housing provision in the 1980s. The Conservatives came to power in 1979 with a relatively clear sense of purpose regarding housing: to promote home ownership and radically reduce, if not eliminate, state provision. In his recent survey of twentieth-century Britain, David Edgerton argues that the fire sale of council housing in the 1980s was as much an offloading of 'modern public capital' as the privatization of industries like British Telecom or British Gas. ${ }^{18}$ The 1980 Housing Act enshrined the Right to Buy council housing in law, with large discounts for sitting tenants leading to a calamitous decline in council housing stock. Housing associations were intended as their replacement, having been seen as more effective 'agents of inner-city rehabilitation' by central government since the $1970 \mathrm{~s} .{ }^{19}$ Later in the period, the 1988 Housing Act deregulated private renting and increased the reliance of housing associations on private finance. ${ }^{20}$ Institutionalized racism, had of course, limited access to council housing for black people well before the 1980s. Black tenants tended to be allocated either older properties or flats on less desirable estates. ${ }^{21}$ Young people under the age of 25 were denied access to the waiting list of Birmingham City Council prior to 1980, and council house sales reduced the chances of securing accommodation for homeless black youths still further. The work of HSHAG acts as a lens onto how housing privatization increased housing inequality in Britain in the latter part of the twentieth century.

Utilizing an organizational history of HSHAG, this article explores 1980s innercity policy in the light of black youth homelessness and the transforming welfare state over two broad sections. The first section introduces HSHAG as a voluntary organization, setting out the context of inner-city funding programmes before questioning the sustainability of urban initiatives for the voluntary sector. The second section examines the effects of housing privatization and unemployment, reflecting how these structural forces undermined the attempts of HSHAG to support homeless black youths. Throughout, the article exposes the relationship of the voluntary sector to the neoliberal state, considering how de-industrialization and harsher approaches to welfare made the task of homelessness organizations Herculean.

\section{The voluntary sector and inner-city policy}

The Handsworth Single Homeless Action Group was effectively the product of an inner-city policy focus. Following the introduction of the Urban Programme in

\footnotetext{
${ }^{17}$ S. Peplow, Race and Riots in Thatcher's Britain (Manchester, 2019), 2.

${ }^{18}$ D. Edgerton, The Rise and Fall of the British Nation: A Twentieth Century History (St Ives, 2018), 455.

${ }^{19}$ P. Malpass, Housing Associations and Housing Policy: A Historical Perspective (Basingstoke, 2000), 160.

${ }^{20}$ Ibid., 202.

${ }^{21}$ J. Henderson and V. Karn, Race, Class and State Housing: Inequality and the Allocation of Public Housing in Britain (Aldershot, 1987), 82.
} 
1968, the voluntary sector ballooned in size across urban Britain, stimulated by the aim of increasing welfare provision in deprived, ethnically diverse inner-city areas. $^{22}$ Although the Urban Programme after 1977 became something of an 'ersatz regional policy' aimed at job creation, with a greater role for seven 'Inner City Partnership' areas which included Birmingham, 'urban aid' remained a voluminous pot for voluntary groups to apply to into the late $1980 \mathrm{~s}^{23}$ The attraction of this funding was underscored by the West Midlands County Council inquiry into the 1985 Handsworth Riot (with authors including Paul Gilroy and Stuart Hall), which critiqued the scrambling of community groups to participate in the handout lottery' of the 'twilight world of grant-competition'. ${ }^{24}$ Inner-city policy programmes were multitudinous, and the use of 'inner-city policy' here mainly refers to the Urban Programme, distributed via the Birmingham Inner City Partnership. The Partnership reported in 1986 that voluntary action was of particular importance in generating a spirit of self-help', having allocated $£ 9.8$ million or 34 per cent of total expenditure to such projects for the next three years. ${ }^{25}$ But this superficially generous fund was reliant on a certain sleight of hand. Local authority budgets fell drastically, through government reductions to the rate support grant and a cap on raising revenue. Effective de-municipalization alongside ongoing de-industrialization presented a considerable challenge for voluntary organizations, especially those focused on the most vulnerable. What, then, does the life-course of an organization such as HSHAG suggest about the role of the voluntary sector in the restructuring of the welfare state?

Handsworth saw an enormous rise in community-focused voluntary organizations through the late 1960s and 1970s. In keeping with other major British cities of the period, notably in London, Manchester and Sheffield, many of these organizations drew inspiration as well as some of their membership from the countercultural, Marxist-influenced 'new left' of the 1960s - a hub of this current being the Centre for Contemporary Cultural Studies (CCCS) at the University of Birmingham, led by Stuart Hall - which had spurred a radical politics of identity based around ethnicity, gender and sexuality. This meeting of political activists, community workers and local government officers in common organizations, gradually orientated towards the Labour party as the 1970s wore on, with the aim of capturing local government for socialist politics based on popular empowerment, was designated by John Gyford as a 'new urban left'. ${ }^{26}$ In contrast with the more significant sites of local socialism in the period, the new urban left in Birmingham never won control of the local Labour party from the party right,

\footnotetext{
${ }^{22}$ M. Hilton and J. McKay (eds.), The Ages of Voluntarism: How We Got to the Big Society (Oxford, 2011), 'Introduction', 1-27. See Radhika Natarajan for the existing governmental and voluntary sector interest in developing community via a pseudo-imperial paternalism in areas of high Commonwealth immigration, which the Urban Programme built upon: R. Natarajan, 'Organizing community: Commonwealth citizens and social activism in Britain, 1948-1982', University of California Berkeley Ph.D. thesis, 2013.

${ }^{23}$ Saumarez Smith, 'Action for cities', 282.

${ }^{24}$ IRR/H, 01/04/04/01/14/07, R. Bhavnani, J. Coke, P. Gilroy, S. Hall, H. Ouseley and K. Vaz, A Different Reality: An Account of Black People's Experiences and Their Grievances Before and After the Handsworth Rebellion of September 1985 (1986), 36.

${ }^{25}$ Birmingham Inner City Partnership, Programme 1986-1989 (1986), 8.

${ }^{26}$ J. Gyford, The Politics of Local Socialism (London, 1985), 17.
} 
although left ideas around decentralization of public services permeated to a limited extent, and, as will be discussed, generous inner-city funding from central government more than compensated for the lack of Greater London Council-style grants. ${ }^{27}$ Perhaps the purest expression of the new urban left trend was the Action Centre on 40 Hall Road, founded by students from the CCCS at the University of Birmingham, which provided a multifaceted advice service as well as seeking to raise class consciousness. ${ }^{28}$ Influenced by the Black Power movement, a number of black organizations aimed to develop the political awareness of the black community whilst also providing welfare services, with one such example being the Harambee hostel for homeless black youths. ${ }^{29}$ An important moment in the evolution of this new voluntary sector was the creation of the Lozells Social Development Centre (LSDC) in 1974. Situated on Finch Road in the Lozells area of Handsworth, with an accompanying 'LSD' club attached as a means of generating revenue, the LSDC served as a hub for an array of voluntary organizations, including HSHAG when it was first formed in 1977. HSHAG founding member Sue Fallon recalled the presence of anti-racist organization All Faiths For One Race (AFFOR), the Trinity Housing Advice Centre, radical arts group Banner Theatre, a group of left-wing town planners called Community Planning, a branch of the Sinn Féin support organization Clann na hÉireann and a wholefoods shop run by activist broadcaster Charlie Parker. ${ }^{30}$ Several organizations were funded by the Barrow and Geraldine S. Cadbury Trust (hereafter referred to as 'Barrow Cadbury') - the charitable foundation of the Cadbury family of Quaker confectioners - via their 'neighbourhood development' and 'race relations' streams. ${ }^{31}$

A direct product of this world of left-wing activism and well-resourced voluntary work, HSHAG encompassed representatives of the Handsworth voluntary sector, such as the Asian Resource Centre and Harambee, alongside those of the local state such as the Birmingham City Council Housing Department and the Community Relations Council. Writing to Charles Cadbury in 1979, the Barrow Cadbury executive secretary Anthony Wilson described the group as people 'who know their way around various corners of the housing world'. ${ }^{32}$ Two key founder members, Fallon and Geoff Wilkins, had set up the Trinity Housing Advice Centre within the LSDC. Neither originated from Handsworth, and both were white, but their backgrounds were otherwise quite different. Fallon had lived in a Handsworth house with nine others, residing in 'one room with a stove, cold water tap, outside toilet' before volunteering at the Action Centre, while Wilkins was a Cambridge graduate who became involved in AFFOR at the end of a Community Service Volunteer placement. ${ }^{33}$ The first key worker employed by HSHAG, the Caribbean-born Dave Butchere, had been an active, then victimized, trade unionist,

\footnotetext{
${ }^{27}$ Ibid., 76 .

${ }^{28}$ C. Critcher, 'Action not words: neighbourhood activism and cultural studies', in K. Connell and M. Hilton (eds.), Cultural Studies 50 Years On: History, Practice and Politics (London, 2016), 247-56, at 248.

${ }^{29}$ Connell, Black Handsworth, 42.

${ }^{30}$ Interview with Sue Fallon, 20 Nov. 2018.

${ }^{31}$ M. Waterson and S. Wyndham, A History of the Barrow Cadbury Trust (London, 2013), 93.

${ }^{32}$ BA/BCC, MS/1579/2/7/1/6, letter from Anthony Wilson to Charles Cadbury, 24 Apr. 1979.

${ }^{33}$ Interview with Sue Fallon, 20 Nov. 2018; interview with Geoff Wilkins, 28 Jun. 2018.
} 
as well as a member of the small revolutionary socialist organization Big Flame best known for having an autonomist, left-libertarian character, influenced by Italian left groups such as Lotta Continua - and went on to become the public face of the group. Conversely, the second key worker to join him, Errol Whitter, also of African-Caribbean heritage, was remembered by Fallon as being 'much more conservative, with a small " $\mathrm{c}$ ". 34 In addition to the minimal staff body and other group representatives, HSHAG had a pool of around 15 volunteers to draw upon. In a similar vein to several other voluntary organizations with a new urban left character, HSHAG were relatively media-savvy, regularly being reported on in the local press, as well as having their early reports cited by The Times and the Guardian, and being featured by Central TV in the 1983 documentary referred to earlier in this piece. ${ }^{35}$ Securing initial funding from Barrow Cadbury, HSHAG initially proposed to act as a housing broker between housing associations and the existing organizations Harambee and the Asian Resource Centre. Their plan was quickly superseded by the more ambitious aim of housing clients themselves and, significantly, was made possible by inner-city funding.

Reviewing their first three years of operation in 1982, the Birmingham Inner City Partnership noted that $£ 670,000$ had been granted to voluntary organizations to '[meet] personal social needs' as well as undertake 'general community work'. ${ }^{36}$ This was a 'very general, loose and trust-dependent grants regime' without the strategic oversight that would become a condition of state funding in the late 1990s. ${ }^{37}$ Throughout most of the 1980s, voluntary organizations in Handsworth could theoretically be funded by the Inner City Partnership Programme (ICPP), the Manpower Services Commission (MSC) and the Handsworth Task Force (set up in response to the 1985 Handsworth Riot), as well as the Birmingham City Council and West Midlands County Council (prior to abolition in 1986). While the voluntary sector seemed to be flourishing, this concealed relative instability. Although HSHAG were funded continuously via the ICPP until 1987, when some Urban Programme schemes came under the control of Birmingham City Council, their loss of funding in 1989 caused a rapid decline in advocacy work. The primary element of HSHAG became the Handworth Single Homeless Housing Association Limited (HSHHAL), as a partner to the larger Midland Area housing association.

The fiscal fragility that characterized HSHAG was largely banal. Group hostels were consistently in deficit and the reliance of clients on benefit payments to pay the rent increased this frailty. Even at the high point of inner-city largesse in 1984, when HSHAG were 81 per cent funded by the ICPP, the majority of this went on worker salaries, furniture for flats and repairs. ${ }^{38}$ The ICPP practice of

\footnotetext{
${ }^{34}$ Interview with Sue Fallon, 20 Nov. 2018. In a famous image by the photographer Vanley Burke, Dave Butchere is pictured being grabbed by a police officer at an anti-National Front demonstration in Saltley in 1978.

${ }^{35}$ 'Young blacks' home plight', Guardian, 5 Apr. 1980; 'Black youths bear the brunt of unemployment', Times, 11 Sep. 1980, 18.

${ }^{36}$ Birmingham Inner City Partnership, Partnership Review 1979-1982 (1982), 18.

${ }^{37} \mathrm{~J}$. Kendall, 'The mainstreaming of the third sector into public policy in England in the late 1990s: whys and wherefores', Policy \& Politics, 28 (2000), 541-62, at 546.

${ }^{38} \mathrm{BA} / \mathrm{BCC}, \mathrm{MS} / 1579 / 2 / 7 / 3 / 29$, HSHAG, Report 6, 16.
} 
paying grants in arrears caused considerable issues, in one instance forcing the group to request $\mathfrak{E 6 , 0 0 0}$ from Barrow Cadbury in 1983 to cover the salary of a hostel warden. ${ }^{39}$ On the sole occasion that HSHAG were successful in receiving funding from the Manpower Services Commission's Community Programme, the tight criteria by which the programme operated meant that HSHAG could only employ an administrative worker for one year. ${ }^{40}$ Real-term cuts to benefits by the Conservative government in 1982 and the abolition of the supplementary benefit in 1986 created a permanent problem of rent arrears. ${ }^{41}$ As HSHAG reflected, the supplementary benefits upon which their clients depended did not keep pace with 'inflationary rate, rent and fuel rises'. ${ }^{42}$ The increasing cost of HSHAG hostels in 1985 meant that the group had to request that the local Department of Health and Social Security (DHSS) office covered running costs, given that clients had their rent paid directly through benefits. ${ }^{43}$ As HSHAG were in 1987 granted $£ 3,000$ by the homelessness charity Crisis to cover a 'hostel deficit' bill, even if the DHSS had complied with their request it was apparently not sufficient. ${ }^{44}$ In 1988 , the switch by the DHSS to paying benefits direct to clients was suggested by HSHAG to have had a calamitous effect on rent income. ${ }^{45}$ The case of HSHAG illustrates that the inner-city funding did little to solidify the ability of the voluntary sector to either '[meet] personal social needs' or undertake 'general community work'.

These constraints can be seen in the constant petitioning of Barrow Cadbury for small grants. Upon receiving ICPP funding in 1980, HSHAG required Barrow Cadbury support for a deficit of $£ 3,000 .{ }^{46}$ Part of the problem was that ICPP funding did not cover certain forms of expenditure, such as vehicle costs, though Butchere's van was central to the HSHAG operation as a means of transporting clients, their furniture and heavy equipment to flats. Barrow Cadbury subsequently paid out $£ 3,000$ for the cost of a new HSHAG van in $1983 .{ }^{47} \mathrm{~A}$ grant for $£ 839$ to be spent on a 'heavy duty vacuum cleaning system' for HSHAG hostels was approved in 1985, owing to the fact that ICPP grants did not cover 'exceptional costs' ${ }^{48}$ The legal and professional costs of becoming a housing association, amounting to $\mathfrak{E} 850$, were met by Barrow Cadbury in $1986 .{ }^{49}$ Barrow Cadbury had by the end of the decade moved away from 'top-up' grants, making the operating practice of HSHAG unfeasible. Wilson explained: '[we shifted] our operating principles to fewer grants and larger, on the grounds that if we were going to support an organization, we should give it enough to make a difference' ${ }^{50}$ This latter point is instructive. Fallon recalled that Wilson would 'take a punt when there

\footnotetext{
${ }^{39}$ BA/BCC, MS/1579/2/7/3/29 Barrow Cadbury, quarterly meeting minutes, 3 Mar. 1983.

${ }^{40} \mathrm{BA} / \mathrm{BCC}, \mathrm{MS} / 1579 / 2 / 7 / 3 / 29$, HSHAG, minutes, 11 Mar. 1984.

${ }^{41}$ H. Glennerster, British Social Policy 1945 to the Present (Oxford, 2007), 181-2.

${ }^{42}$ IRR/H, 01/04/04/01/14/07, HSHAG, Report 4, 19.

${ }^{43}$ BA/BCC, MS/1579/2/7/3/29, HSHAG, minutes, 24 Jun. 1985.

${ }^{44} \mathrm{BA} / \mathrm{BCC}, \mathrm{MS} / 1579 / 2 / 7 / 3 / 29$, HSHAG, minutes, 19 Jan. 1987.

${ }^{45} \mathrm{BA} / \mathrm{BCC}, \mathrm{MS} / 1579 / 2 / 7 / 3 / 29$, HSHAG, minutes, 18 Apr. 1988.

${ }^{46} \mathrm{BA} / \mathrm{BCC}$, HSHAG, minutes, 5 Jun. 1980.

${ }^{47}$ BA/BCC, MS/1579/2/7/3/29 Barrow Cadbury, quarterly meeting agenda note, 16 Oct. 1983.

${ }^{48} \mathrm{BA} / \mathrm{BCC}, \mathrm{MS} / 1579 / 2 / 7 / 3 / 29$ Barrow Cadbury, quarterly meeting minutes, 8 Dec. 1985.

${ }^{49}$ BA/BCC, MS/1579/2/7/3/29 Barrow Cadbury, quarterly meeting minutes, 19 Nov. 1986.

${ }^{50}$ Interview with Anthony Wilson, 25 Jul. 2018.
} 
wasn't necessarily a lot of evidence', but Wilson himself suggested that prior to his retirement in 1993 Barrow Cadbury had begun to reorient away from grant-making and towards 'expertly developing public policy'. ${ }^{51}$ The limits of philanthropy were laid bare at the end of the decade. When HSHAG finally lost ICPP funding in 1989 and requested $\mathfrak{E} 36,000$ over three years to pay worker salaries, Barrow Cadbury granted only $\mathfrak{E 6 , 0 0 0}$ over six months as a 'special case. ${ }^{52}$

Supporting homeless black youths sustainably required considerably more investment than inner-city policy could provide. In the case of housing, the funding provided by inner-city programmes was most valuable to voluntary organizations that could adequately scale up to absorb the effects of funding withdrawal at the end of the 1980s. The requirement of the 1988 Housing Act for housing associations to raise capital on the open market made it difficult for smaller, specialist bodies to operate, particularly if they had an activist character like HSHAG. ${ }^{53}$ Former group secretary Gina King recalled that the funding got directed to [large] housing associations....so that grassroots stuff all dried up' ${ }^{54}$ If inner-city policy on the part of central government did not offer a coherent message towards the voluntary sector, it is evident that the same policy laid the groundwork for a system of more tightly managed grants and a far closer integration of the mixed economy of welfare. Colin Rochester has suggested that by the New Labour era the voluntary sector was 'no longer seen as valuable in its own right, but as useful to government as a means to achieving its own ends'. ${ }^{55}$ The 1980 s seems, then, to have represented a time in which central government saw the voluntary sector as 'a means to achieving its own ends', but lacked any co-ordinated sense of how it might do so.

\section{Black youth homelessness}

Returning to the 1983 documentary, an interview between Dave Butchere and a young woman called Sherry gave a vivid example of how easily homelessness could arise. When Sherry was asked how many people lived in her family home, she replied that she lived with nine siblings as well as her parents, sharing a bed with three of her sisters. This was far from unusual. A 1979 Department of the Environment survey reported that over half of the African-Caribbean population of Birmingham lived in overcrowded conditions. ${ }^{56}$ Sherry went on to say that her parents had told her to find a place for herself. Although the initial focus of HSHAG was on young single men, women generally formed half of the HSHAG client base at any given time. Indeed, according to a 1991 study of single homelessness, black women tended to form a disproportionately large part of the homeless population. ${ }^{57}$ Following the interview, Butchere notes that Sherry 'does not get on

\footnotetext{
${ }^{51}$ Interview with Sue Fallon, 20 Nov. 2018; interview with Anthony Wilson, 25 Jul. 2018.

${ }^{52}$ BA/BCC, MS/1579/2/7/4/17, Barrow Cadbury, quarterly meeting minutes, 19 Mar. 1989.

${ }^{53}$ Malpass, Housing Associations and Housing Policy, 203.

${ }^{54}$ Interview with Gina King, 14 Sep. 2018.

${ }^{55}$ C. Rochester, Rediscovering Voluntary Action: The Beat of a Different Drum (Basingstoke, 2013), 74.

${ }^{56}$ Henderson and Karn, Race, Class and State Housing, 30.

${ }^{57}$ P.A. Kemp, 'Characteristics of single homeless people, England', in R. Burrows, N. Pleace and D. Quilgars (eds.), Homelessness and Social Policy (London, 1997), 69-88.
} 
with her mother. They have continual arguments. ${ }^{58}$ This theme continued with a second HSHAG client interviewed in the documentary, a young man aged 17 named Paul who had been thrown out of the family home after adopting a Rastafarian lifestyle. He recounted how he 'wanted to go out places but they [his parents] wouldn't let me. So one day I just went out and I didn't come back. ${ }^{59}$ In his new flat (with a Haile Selassie poster on the wall), Paul stated that he 'preferred to stop out here' than to renounce Rastafarianism and return to the family home. ${ }^{60}$ The making of the documentary - with Central TV having approached HSHAG for the 30-minute film - reflected a growing public awareness of the conditions faced by young black people in 1980s Britain, laid bare by the 1981 riots. Though it is not exactly clear how the documentary was received by audiences, it was broadcast at the prime time slot of 7:30pm on Thursday 11 August $1983 .{ }^{61}$ Both interviewees had been made homeless by family conflict and material poverty, circumstances that were compounded by the rapid de-industrialization, worsening housing inequality and entrenched racial disadvantage that characterized the 'urban crisis'. This section will examine how the combination of closing factories, council house sales and endemic discrimination severely constrained the ability of HSHAG to support those in need.

Reflecting on the foundation of the group, Fallon recalled that the Trinity Housing Advice Centre had seen 'a lot of young men who were either actually homeless or they were sleeping on sofas' and as 'people were frightened of young black men...nobody was really helping them'. ${ }^{2}$ Much of this fear was driven by the racist idea that young black men were all potentially dangerous 'muggers'. As the authors of the 1978 CCCS study Policing the Crisis suggested - some of whom moved in the same circles as HSHAG members - a 'typical biography' for the young black men generally stereotyped as 'muggers' was one of vulnerability rather than of supposed menace. In this character sketch, protracted unemployment and family conflict led to a life of homelessness, with the threat of police searches or arrest an ever-present threat of being on the streets after dark. ${ }^{63}$ The growth in Rastafarian culture amongst the young in Handsworth served to set 'black youth' apart further from social norms as well as stoke family conflict - as Paul's story in the documentary demonstrates - with an older generation highly suspicious of the subculture. ${ }^{64}$ Alongside the reasons for homelessness given above, HSHAG's first annual report in 1979 included: parents having returned to the Caribbean; those who had been in local authority care and lost support on reaching 18; and those who had 'lost their home through the vicissitudes of the rented-accommodation market'. ${ }^{65}$ A further report in 1980 found that most were part of what is conventionally termed the 'hidden homeless', living in 'a continual

\footnotetext{
${ }^{58}$ MACE, Homeless in Handsworth.

${ }^{59} \mathrm{Ibid}$.

${ }^{60} \mathrm{Ibid}$.

${ }^{61} \mathrm{BA} / \mathrm{BCC}, \mathrm{MS} / 1579 / 2 / 7 / 3 / 29$, HSHAG, minutes, 20 Jun. 1983.

${ }^{62}$ Interview with Sue Fallon, 20 Nov. 2018.

${ }^{63}$ S. Hall, C. Critcher, T. Jefferson, J. Clarke and B. Roberts, Policing the Crisis: Mugging, the State and Law and Order, 2nd edn (Basingstoke, 2013), 354.

${ }^{64}$ Connell, Black Handsworth, 94.

${ }^{65}$ BA/BCC, MS/1579/2/7/1/6, HSHAG, First Report (1979), 4.
} 
state of insecurity' and staying either in 'fairly long term (but nearly always overcrowded) arrangements' with friends and relatives, or 'sofa-surfing' from night to night. $^{66}$ Other British cities had experienced a similar phenomenon of black youth homelessness from the late 1960s onwards. The Harambee hostel in Handsworth had been set up in response to this trend, following the eponymously named hostel on the Holloway Road in London better known as the 'Black House. ${ }^{67}$

By the foundation of HSHAG in 1977, unemployment had risen sharply, manufacturing jobs having declined in number by 22.5 per cent within inner-city Birmingham between 1971 and 1976. Around 44 per cent of inner-city households were recorded as receiving free school meals in 1976 against 29 per cent for Birmingham as a whole. ${ }^{68}$ With familial poverty rising and fewer jobs for black youths entering the economy, the numbers becoming homeless were accordingly higher. Fallon's recollection that 'nobody was really helping them' rang true. The Harambee hostel was restricted in size, having space for only 19 individuals with an upper age limit also of 19. Single homeless persons under the age of 25 were prohibited from joining the council house waiting list in Birmingham, whilst housing associations were unenthusiastic about renting to homeless black youths, believing that they would be a 'nuisance to neighbours' as well as unable to pay rent. ${ }^{69}$ HSHAG aimed to soften the attitude of housing associations to the young single homeless black population, through directly managing 'hard-to-let' properties granted to them by friendly housing associations and jointly applying for inner-city funding. At the same time, the group aimed to open up the council house waiting list to their clientele, as well as advocating for their rights to employment and housing in Birmingham more generally.

In the midst of an increasingly unequal housing market, such advocacy was essential. Most of the housing stock in Handsworth had been built prior to 1919, and a fifth of households across central Birmingham still lacked exclusive use of basic amenities such as a fixed bath, toilet or hot water supply. Though the number of council tenancies amongst African-Caribbean families in the city was rising by the late 1970s, tenancies were overwhelmingly concentrated within inner-city areas - which contained a fairly low proportion of council housing. ${ }^{70}$ Securing a council tenancy in Handsworth itself, or on the neighbouring Newtown estate in Aston, was thus relatively difficult. Council tenancies allocated were often two-bedroom flats or compulsorily purchased pre-1919 housing of the type otherwise owned by black families, which did not solve overcrowding. ${ }^{71}$ The onset of the Right to Buy in 1980 accelerated residualization within council housing: one million sales left the poor, unemployed and elderly in the majority of the remaining tenants. ${ }^{72}$

\footnotetext{
${ }^{66} \mathrm{BA} / \mathrm{BCC}, \mathrm{MS} / 1579 / 2 / 7 / 1 / 6$, HSHAG, Report 2 (1980), 2 and 3-4.

${ }^{67}$ Connell, Black Handsworth, 42. The 'Black House' became infamous due to its association with the controversial activist Michael de Freitas, known as Michael X.

${ }^{68}$ Birmingham Inner City Partnership, Birmingham Inner City Profile 1980 (1980), 8 and 15.

${ }^{69}$ BA/BCC, MS/ 1579/2/7/1/6, HSHAG, First Report, 2.

${ }^{70}$ Henderson and Karn, Race, Class and State Housing, 32.

${ }^{71}$ Ibid., 38.

${ }^{72} \mathrm{P}$. Malpass, Housing and the Welfare State: The Development of Housing Policy in Britain (Basingstoke, 2005), 114.
} 
The supposed alternative, the private rented sector, was in near-terminal decline, forming around 11 per cent of the housing stock in $1981 .{ }^{73}$ Nor was the average landlord particularly amenable to black tenants, and especially not black homeless youths without deposits. In a 1982 survey, around half of African-Caribbean respondents reported being refused private rented accommodation due to their skin colour. ${ }^{74}$ Although the 1976 Race Relations Act had empowered local Community Relations Councils to receive and act upon complaints of discrimination, the lengthy litigation process and burden of proving discrimination might have meant HSHAG was disinclined to directly challenge private landlords refusing to rent to black homeless youths. Despite high rents and long waiting lists, housing associations were the only real alternative for HSHAG clients. King recalled there being 'about twelve' housing associations operating within Handsworth alone, and HSHAG cultivated close relationships with housing associations such as Midland Area and Christian Conference on Politics Economics and Citizenship (COPEC) as a means of gaining a supply of 'hard-to-let' properties. ${ }^{75}$ It was, however, questionable as to whether this would be sufficient in an era in which the (always unsteady) notion of housing as a right that could be demanded from the state began to collapse.

The right to state housing was even more precarious in the case of the homeless population. Although the 1977 Housing (Homeless) Persons Act established the statutory duty of councils to house the homeless population, it pandered to the wishes of local authorities by failing to define vulnerability and prioritizing families over single people. As Nick Crowson writes, the act reinforced the idea that 'individual deviancy had led the single towards homelessness'. ${ }^{76}$ This attitude was clearly present in Birmingham. HSHAG stated in 1980 that only nine single homeless black people had been actually rehoused, with the successes coming from HSHAG workers arguing their case at a housing centre for 'a large part of the day. ${ }^{77}$ Things did not improve as the decade wore on. With grim irony, the group observed in 1986 that HSHAG clients who did not gain a housing association flat were more likely to go on to prison than to be rehoused by the council. ${ }^{78}$ Just 60 of 940 former HSHAG clients had been rehoused by the council by $1988 .^{79}$ Homeless black tenants faced further challenges if they were offered council accommodation in the predominantly white outer districts of Birmingham. Butchere commented in the 1983 documentary that HSHAG clients had lasted 'about two to three weeks' in peripheral districts like Northfield and Rubery before being 'back in Handsworth, homeless again'. ${ }^{80}$ This was a consequence, Butchere suggested, of the suburban outskirts of Birmingham being an essentially alien

\footnotetext{
${ }^{73}$ T. Crook and P.A. Kemp, Transforming Private Landlords: Housing, Markets and Public Policy (London, 2011), 54.

${ }^{74}$ C. Brown, Black and White Britain: The Third PSI Survey (London, 1984), 84.

${ }^{75}$ Interview with Gina King, 14 Sep. 2018.

${ }^{76} \mathrm{~N}$. Crowson, 'Revisiting the 1977 Housing (Homeless Persons) Act: Westminster, Whitehall, and the homelessness lobby', Twentieth Century British History, 24 (2013), 445-6.

${ }^{77} \mathrm{BA} / \mathrm{BCC}, \mathrm{MS} / 1579 / 2 / 7 / 1 / 6$, HSHAG, Report 2, 8.

${ }^{78} \mathrm{BA} / \mathrm{BCC}, \mathrm{MS} / 1579 / 2 / 7 / 3 / 29$, HSHAG, Report 7 (1986), 5.

${ }^{79}$ BA/BCC, MS/1579/2/7/4/17, HSHAG, Report 8 (1988), 8.

${ }^{80}$ MACE, Homeless in Handsworth.
} 
environment for young black people estranged from friends, family and familiar food. More ominously, he raised the threat of racist violence on outer housing estates, whether randomized or from 'sections of the National Front' who were 'prepared to use any means necessary to intimidate or to attack black people who live in their areas, because they wish for their areas to remain white. ${ }^{81}$ Less than a third of respondents to a 1984 survey of the British black population believed that they could rely on the police to protect them from racial violence. ${ }^{82}$ For homeless black youths, this narrowed an already limited pool of council housing, as well as adding to a sense of alienation from British society at large.

HSHAG had considerably more success referring clients to housing associations. Hostels, the traditional destination of homeless individuals, were in turmoil in the 1980s. Older, larger hostels were closed throughout the decade in favour of smaller institutions based on referral, resulting in an overall loss of bedspace and making it difficult for homeless persons coming off the street to get a place. ${ }^{83}$ Though most of their clients were engaged in 'sofa-surfing', HSHAG reported in 1982 that

we have at times had up to 20 youngsters for whom we have been unable to find a hostel-place in the whole of Birmingham. As most are usually out of work and without sufficient funds in their pocket for even one night's stay in a commercial hostel, the only remaining option for most is to squat, often in appalling conditions, or to sleep rough on park benches or in New Street station. ${ }^{84}$

The bar for success was accordingly low, aiming to provide 'respite from the constant round of stopping with friends' ${ }^{85}$ However, as most housing associations that HSHAG dealt with were 'more interested in housing safe, politically non contentious client groups [such as] families and the elderly', the key workers had to constantly negotiate housing places for their clients. ${ }^{86}$ These took the form of emergency housing flats or bedsits, which key workers did not directly manage but rather selected tenants and provided 'day to day support. ${ }^{87}$ From 1980, HSHAG operated a special accommodation scheme for 'younger and more vulnerable female clients' in a three-storey house converted by the housing association COPEC into pairs of bedsits sharing a kitchen and bathroom, with an 'older and more responsible woman' living rent-free as scheme caretaker ${ }^{88}$ Such arrangements became commonplace across Britain in the 1980s, rising from 500 such schemes to 3,000 between 1980 and $1990 .{ }^{89}$

Trouble paying the rent was a key reason that homeless black youths were considered less 'safe' by housing associations than other client groups. Unemployment

\footnotetext{
${ }^{81}$ Ibid.

${ }^{82}$ Brown, Black and White Britain, 321.

${ }^{83}$ Drake, 'Fifteen years of homelessness in the UK'.

${ }^{84} \mathrm{IRR} / \mathrm{H}, 01 / 04 / 04 / 01 / 14 / 07$, HSHAG, Report 4, 21.

${ }^{85} \mathrm{BA} / \mathrm{BCC}, \mathrm{MS} / 1579 / 2 / 7 / 1 / 6$, HSHAG, Report 2, 6.

${ }^{86} \mathrm{IRR} / \mathrm{H}, 01 / 04 / 04 / 01 / 14 / 07$, HSHAG, Report 5 (1983), 4.

${ }^{87} \mathrm{IRR} / \mathrm{H}, 01 / 04 / 04 / 01 / 14 / 07$, HSHAG, Report 3 (1981), 14.

${ }^{88}$ Ibid., 13.

${ }^{89}$ J. Neale, 'Hostels: a useful policy and practice response?', in Burrows, Pleace and Quilgars (eds.), Homelessness and Social Policy, 203-15.
} 
amongst the African-Caribbean community in Britain stood at 24 per cent at the height of the early 1980s recession in 1982, with the proportion rising to 42 per cent amongst young black men aged under $25 .{ }^{90}$ This rose still higher for homeless black youths. More than 50 per cent of all new HSHAG clients in 1980 were recorded as unemployed and claiming supplementary benefits. Of those who were working, 67 per cent earned less than $£ 40$ a week, and the group commented, 'a life of semi-homelessness is not particularly conducive to securing or keeping a job.' ${ }^{91}$ By 1982, the proportion of unemployed clients had risen to 76 per cent. ${ }^{92}$ Surveying their work over a 10-year period in 1988, HSHAG noted that of all 3,852 clients seen in that period, 60 per cent were unemployed, 16 per cent employed or self-employed and the remainder on MSC schemes or in education. ${ }^{93}$ A life on supplementary benefits was choosing between paying the rent and eating properly. One young man supported by HSHAG described in the 1983 documentary how he spent his benefit in full 'the same day I get it', subsisting in the second half of the week on flour dumplings or going hungry. ${ }^{94}$ Perhaps unsurprisingly, mental health problems amongst clients were increasingly a concern for HSHAG in the latter part of the 1980s, with two separate instances of tenants setting their flats alight reported in $1987 . .^{95}$

Apart from rent arrears, trouble with the police was an acute danger for HSHAG tenants. HSHAG properties, acting as small concentrations of jobless young black individuals, in some respects '[signified] the fragile nature of the order which police are able to impose' and therefore presented a threat. ${ }^{96}$ One early HSHAG scheme in Baker Street of six terraced houses was deemed to have failed when a group of tenants already under surveillance by the police invited numerous homeless friends to stay, with five of the six houses described by Wilkins as a 'sordid and dilapidated squat'. ${ }^{97}$ The police subsequently raided the properties throughout 1979 , charging some of the tenants with criminal offences. ${ }^{98}$ HSHAG responded to the problem by ejecting the tenants in question and attempting to approach the local police superintendent, but it would seem the damage was already done, with the Baker Street houses described as 'a boil on Handsworth's arse' by a local police constable. ${ }^{99}$ Staff had their own issues with police, with Dave Butchere in particular being 'fitted up' with dubious charges on two occasions in 1981 and 1988: the first, involving the claim that his possession of a rounders bat indicated violent intent; and the second, for 'abusive language' after being followed to his car by police after a late anti-cuts meeting. ${ }^{100}$ Neither charge was upheld in court. Noise complaints also attracted

\footnotetext{
${ }^{90}$ Brown, Black and White Britain, 174 and 190.

${ }^{91}$ BA/BCC, MS/1579/2/7/1/6, HSHAG, Report 2, 4.

${ }^{92}$ IRR/H, 01/04/04/01/14/07, HSHAG, Report 4, 6.

${ }^{93} \mathrm{BA} / \mathrm{BCC}, \mathrm{MS} / 1579 / 2 / 7 / 4 / 17$, HSHAG, Report 8, 7.

${ }^{94} \mathrm{MACE}$, Homeless in Handsworth.

${ }^{95}$ BA/BCCMS 1579/2/7/3/29, HSHAG, minutes, 2 Nov. 1987.

${ }^{96}$ P. Gilroy, There Ain't No Black in the Union Jack: The Cultural Politics of Race and Nation (London, 1987), 139.

${ }^{97}$ BA/BCC, MS 1579/2/3/3/7, SHAPE, Annual Report 1979-1980 (1980).

${ }^{98}$ HSHAG meeting minutes (14 Dec. 1979).

${ }^{99}$ BA/BCC, MS 1579/2/3/3/7, SHAPE, Annual Report 1979-1980.

${ }^{100}$ BA/BCC, MS 1579/2/7/1/6, letter from Anthony Wilson to Sir Philip Knights, 29 Apr. 1981; MS 1579/2/7/3/29, Barrow Cadbury 'agenda note' (Jan. 1988).
} 
police attention - King had briefly lived in a HSHAG flat and recalled that it was loud music, music all night, you could only sleep in the day'. ${ }^{101}$ The loud music was a reflection of Handsworth's active reggae culture, with powerful sound systems a key feature. ${ }^{102}$ HSHAG nonetheless remained consistent in their view that it was far better to get homeless young people into stable accommodation from which they might improve their lot - even at the risk of offending the neighbours - rather than allowing 'the violence of despair and disillusion' to break out. ${ }^{103}$

In this respect, HSHAG co-ordinated with other Handsworth organizations to develop a range of educational and employment opportunities. In 1980, the group ran a six-week course entitled 'Staying Alive' in collaboration with the Handsworth Workers' Educational Association. With around 20 in attendance each week, sessions included: 'social security, finding a place to live, getting a job, the police and the law, leisure and further education, and sex'. ${ }^{104}$ Courses on the same broad themes would run consistently up to $1988 .{ }^{105}$ A computing course giving 'hands on experience' with Amstrad, IBM and Atari PCs was run over six weeks in 1988, with eight participants at a time. ${ }^{106}$ Clients were encouraged to engage with programmes offered by community arts organizations such as WELD and black educational charities such as ACAFESS, and the group ran a coach trip to Notting Hill carnival for HSHAG tenants in 1984. In addition to this wide range of informal educational work, HSHAG attempted to get their clients onto further education courses through directly approaching local colleges.

Where HSHAG sought to provide employment training, this was primarily intended to address the shortcomings of the Youth Training Scheme (YTS) for those aged between 16 and 18, introduced by the MSC in 1983. Though a range of specialized employment measures had been run by the MSC since its formation in 1973, primarily aimed at rising youth unemployment, the YTS differed in that they were delivered through employers rather than through state bodies. ${ }^{107}$ By 1989, around 16 per cent of all school leavers in Britain entered the YTS, with more than a third of new HSHAG clients on such schemes by the late 1980s. ${ }^{108}$ HSHAG argued that the schemes failed to equip young people with usable skills or combat the 'endemic racism that permeates the organisations, companies and corporations' involved in training. ${ }^{109}$ In a 1987 area study of Handsworth, Birmingham City Council reported that four out of five YTS trainees in Handsworth were unable to find permanent work. ${ }^{110}$ These arguments had been reinforced by the West Midlands County Council inquiry into the 1985

\footnotetext{
${ }^{101}$ Interview with Gina King, 14 Sep. 2018.

${ }^{102}$ Connell, Black Handsworth, 109.

${ }^{103} \mathrm{IRR} / \mathrm{H}, 01 / 04 / 04 / 01 / 14 / 07$, HSHAG Report 3, 1.

${ }^{104}$ BA/BCC, MS/1579/2/7/1/6, HSHAG, Report 2, 6; BA/BCC, MS/1579/2/7/3/29, letter from Dave Butchere to Anthony Wilson, 26 Aug. 1988.

${ }^{105} \mathrm{IRR} / \mathrm{H}, 01 / 04 / 04 / 01 / 14 / 07$, HSHAG, Report 4, 21.

${ }^{106} \mathrm{BA} / \mathrm{BCC}, \mathrm{MS} / 1579 / 2 / 7 / 3 / 29$, Dave Butchere to Anthony Wilson, 26 Aug. 1988.

${ }^{107}$ P.J. Dolton, 'The economics of youth training in Britain', Economic Journal, 103 (1993), 1261-78, at 1264.

${ }^{108}$ Ibid., 1268; BA/BCC, MS/1579/2/7/4/17, HSHAG, Report 8, 5.

${ }^{109} \mathrm{BA} / \mathrm{BCC}, \mathrm{MS} / 1579 / 2 / 7 / 4 / 17$, HSHAG, draft 1990 report, 4.

${ }^{110}$ Birmingham City Council, Handsworth/Soho/Lozells Area Study (May 1987), 8.
} 
Handsworth Riot, which found that the schemes of major Birmingham employers, such as Lucas Aerospace and Jaguar, had no black trainees at all. Other companies were little better. Of 20 trainees at the ammunition manufacturer ICI Kynoch, with a large factory close to Handsworth in Witton, just one was black. ${ }^{111}$ In the 1983 documentary, the same young man who struggled to feed himself on unemployment benefits was asked about his job prospects. He replied that he could not afford smart clothes for an interview and 'they're not going to employ me because I'm a Rasta, because of my hat and my locks'. ${ }^{112}$ His fears were not without foundation. In 1986, The Voice reported that a Rastafarian man aged 21 was fired on his first day of work at an electrical engineering firm in North London for refusing to remove his hat. ${ }^{113}$ Seeking to expand opportunities for jobless black youths beyond the YTS, HSHAG founded the Black Star Car Company in 1989, a non-profit garage. The venture received some funding from the Handsworth Task Force in 1990, though was quickly 'in jeopardy' due to the lack of a permanent funding source to pay the salaries of instructors, and was dissolved in $1994 .{ }^{114}$ The young Rastafarian in the documentary reflected that his job-hunting chances might improve if he cut his hair, but concluded 'there's not enough jobs around anyway, even if I was to cut my hair it wouldn't be worth it.. ${ }^{115}$ It is difficult to argue that he was wrong. Considering the course of the 1980s at the close of the decade, HSHAG asserted that the 'equation of unemployment, housing access, rapidly eroding state benefit and racism' had made their task harder than ever before. ${ }^{116}$ State interventions such as the YTS were a key part of this equation - the schemes did little to address structural racism in the labour market, and rather than reducing unemployment, simply moved some unemployed youths into a different category.

Forming a housing association was one way in which it seemed that HSHAG could increase their control over the housing process. Although housing associations serving the black population had existed since the 1950s - such as the Quaker-led Birmingham Friendship Housing Association, or the Nottingham Coloured People's Housing Society - these organizations were essentially parochial, aiming to quietly assimilate the immigrant population. ${ }^{117}$ The 1970s saw the creation of black-led housing associations seeking greater control for black communities over the housing process, such as Ujamaa (named after the socialist villages of post-colonial Tanzania), founded in North London in $1977 .{ }^{118}$ As mentioned, the period saw relatively generous funding for housing associations, with additional incentives for black housing associations following the 1980-81 riots. Ujamaa welcomed HSHAG workers for a fact-finding mission in 1983, later providing training for special accommodation scheme wardens. ${ }^{119}$ It is probable that the experience

\footnotetext{
${ }^{111}$ IRR/H, 01/04/04/01/14/07, Bhavnani, Coke, Gilroy, Hall, Ouseley and Vaz, A Different Reality, 36.

${ }^{112}$ MACE, Homeless in Handsworth.

${ }^{113}$ Black Cultural Archives (BCA), The Voice, 22 Feb. 1986, 1.

${ }^{114} \mathrm{BA} / \mathrm{BCC}, \mathrm{MS} / 1579 / 2 / 7 / 4 / 17$, HSHAG, draft 1990 report, 5.

${ }^{115}$ MACE, Homeless in Handsworth.

${ }^{116}$ BA/BCC, MS/1579/2/7/4/17, HSHAG, draft 1990 report, 6.

${ }^{117}$ P.B. Rich, Race and Empire in British Politics (Cambridge, 1990), 184.

${ }^{118}$ BCA, The Voice, 30 Oct. 1982, 14-15.

${ }^{119}$ IRR/H, 01/04/04/01/14/07, HSHAG, Report 5, 21; BA/BCC, MS/1579/2/7/3/29, HSHAG, minutes, 16 Jan. 1984.
} 
helped inspire HSHAG to set up their own housing association, which was registered as the Handsworth Single Homeless Housing Association Limited (HSHHAL) in $1986 .^{120}$

The new housing association struggled to find capital for new developments, having by 1990 completed only one block of 24 one-bedroom flats on Villa Street. ${ }^{121}$ The requirement of the 1988 Housing Act was that housing associations fund a large proportion of new development privately rather than relying on allocations from the Housing Corporation. In practice, this meant small housing associations were pushed either into partnership with larger bodies or towards charging high rents to satisfy lenders. ${ }^{122}$ HSHAG reported in 1990 that they could not afford to employ even a single housing officer to manage their existing units. ${ }^{123}$ Creating a robust housing association was an extraordinarily difficult task for an advocacy organization focused on a vulnerable client body. To remain financially viable, HSHAG partnered with their long-time associate Midland Area in the early 1990s. King recalled that '[Butchere] always said [he] made a mistake...they were promised $\mathrm{x} y$ and $\mathrm{z}$, then what happened was they were just submerged'. ${ }^{124}$ As Midland Area became larger through further mergers, by the dawn of the new millennium HSHAG existed simply as a small, specialized section of a major housing association, their advocacy work having disappeared entirely.

In 1993, the Independent reported a trip made to Handsworth by the Social Justice Commission, a body set up by the Labour party charged with reconceptualizing the diminished Beveridgean welfare state. The 1985 riot cast a long shadow over the trip. Unemployment within Handsworth had hit 36 per cent in 1987, and a further outburst of riotous looting in September 1991 after an electricity blackout had solidified political views that the problems of the district were insurmountable. ${ }^{125}$ In a visit to HSHAG, Butchere was asked by the chair of the commission Sir Gordon Borrie how 'more social justice' might be achieved. Butchere suggested that there needed to be something 'that young blacks and other poor people round here can see is directly beneficial to them and [that would give] them some sort of dignity.' ${ }^{126}$ In an obvious repudiation of the Thatcherite approach to welfare, Butchere was calling for equal treatment for homeless black youths in the eyes of the state. The Social Justice Commission would ultimately recommend a harder line on benefits along with wider educational opportunities, which would become New Labour policy to encourage the destitute into work, but is unlikely to have been exactly what Butchere had in mind. ${ }^{127}$ HSHAG and the black youth homeless population were both consequence and casualties of the inner-city policy moment beneficiaries of the hybridization of welfare spending and the victims of its failure.

\footnotetext{
${ }^{120}$ BA/BCC, MS/1579/2/7/3/29, HSHAG, minutes, 7 Apr. 1986.

${ }^{121}$ BA/BCC, MS/1579/2/7/4/17, HSHAG, draft 1990 report, 7.

${ }^{122}$ Malpass, Housing Associations and Housing Policy, 203.

${ }^{123}$ BA/BCC, MS/1579/2/7/4/17, HSHAG, draft 1990 report, 7.

${ }^{124}$ Interview with Gina King, 14 Sep. 2018. Midland Area became Midland Heart in 2006 and is now one of the largest housing associations in the UK.

${ }^{125}$ Birmingham City Council, Handsworth/Soho/Lozells Area Study, 6; Guardian, 3 Sept. 1991, 3.

${ }^{126}$ Independent, 22 Mar. 1993, accessed 9 Mar. 2020: www.independent.co.uk/news/uk/birminghamoffers-a-modern-definition-of-social-injustice-rosie-waterhouse-reports-on-progress-in-1499172.html.

${ }^{127}$ S. Driver, 'Poverty, social justice and the Labour government, 1997-2007', Benefits, 16 (2008), 157-67.
} 


\section{Conclusion}

Established in the late 1980s, the infamous 'Cardboard City' community of several hundred rough sleepers near the Royal Festival Hall in London served as a grim monument to Thatcherism. It was the tip of the iceberg. According to one estimate, as many as one million households - approximately three million people - had been accepted by local authorities as homeless in the decade between 1980 and $1990 .{ }^{128}$ The homelessness charity Shelter expanded on this figure in 1992, estimating that there were as many as 760,000 'hidden homeless' households in England that year alone, as well as around 8,000 rough sleepers of the kind in Cardboard City. ${ }^{129}$ Although the 1980 s was a juncture at which urban black populations attempted to ['shrink] the world to the size of their communities and [begin] to act politically on that basis', in the case of homelessness this local action could never be sufficient. ${ }^{130}$

Inner-city funding was not an effective means of resourcing campaigns on homelessness, even when the 'urban crisis' was in vogue. A paradoxical era, the 1980s encompassed the continuation of the old regime of readily available voluntary funding, a rapid move towards strictly regulated short-lived grants, and increasing government bias for large voluntary organizations capable of operating at scale. In an important sense, this chronicle of expansion then contraction amidst de-industrialization and hardening racial disadvantage serves as an exemplar of 'the variety of trajectories at play in the eighties, their velocity and sometimes their contradictions' described by Stephen Brooke. ${ }^{131}$ Inner-city policy had an incongruous effect on the voluntary sector. It is apparent that the ways in which voluntary organizations adapted to meet new funding criteria and took on greater responsibilities was part of a process by which 'a logic of expert knowledge and professional behaviour' replaced the community-focused, politically motivated operation of organizations such as HSHAG. ${ }^{132}$ The voluntary sector began to move from being a modest part of the 'mixed economy' of welfare to being an alternative to the universalist welfare state. For the most vulnerable in society, the privatization of state housing, chronic unemployment and harsher character of the neoliberal welfare state made the limitations of the voluntary alternative all too obvious.

\footnotetext{
${ }^{128} \mathrm{~J}$. Greve, 'Preface', in Burrows, Pleace and Quilgars (eds.), Homelessness and Social Policy, xi-xvii.

${ }^{129} \mathrm{M}$. Warrington, 'Running to stand still: housing the homeless in the 1990s', Area, 28 (1996), 471-81.

${ }^{130}$ Gilroy, There Ain't No Black, 245.

${ }^{131}$ S. Brooke, 'Living in "new times": historicizing 1980s Britain', History Compass, 12 (2014), 20-32.

${ }^{132}$ M. Hilton, N. Crowson, J.-F. Mouhot and J. McKay, The Politics of Expertise: How NGOs Shaped Modern Britain (Oxford, 2013), 54.
}

Cite this article: Child P (2023). Race, homelessness and inner-city policy in 1980s Britain. Urban History 50, 301-318. https://doi.org/10.1017/S096392682100078X 